Nordisk Tidsskrift for Kriminalvidenskab 2003

\title{
HALVFJERDS ÅR FOR RAKEL - OM REFORMER I NÆVNINGESYSTEMET*
}

\author{
Af dommer Peter Garde
}

This article was delivered as the keynote speech at the latest annual meeting of the Danish Criminalists' Association, where its presentation was followed by a brisk debate. The author reviews suggested reforms of the Danish jury system - today largely constructed on lines corresponding to the Anglo-Saxon system. The proposed reforms encompass deliberation in a common gremium, which allows for, but does not require, the cooperation of court and jury for the whole case and the introduction of an appeal on facts. Such cases would proceed either with a jury in both instances or with a mixed court followed by appeal to a court with jury, the latter preferred by the author. Juries are currently excluded in cases concerning white-collar crime. The author proposes that juries also be excluded in drug cases, and that mixed cases - involving counts for which juries generally are and are not included - be reformed.**

Jakob tjente syv år for Rakel, og de syv år var ham som få dage, fordi han elskede hende, men halvfjerds år varede det og føltes utvivlsomt lige så længe, nærmest som israeliternes ørkenvandring, inden den ved Grundloven af 1849 lovede retsreform gennemførtes i 1919 med indførelse af offentlighed og mundtlighed, selvstændig anklagemyndighed og sidst, men ikke mindst, indførelse af lægdommere i form af nævninger i straffesager. En anden reform har været overvejet og med mellemrum heftigt debatteret i et snart lige så langt tidsspand. Efter indførelsen af domsmænd i $1937 \mathrm{i}$ et meget stort antal af de større og mellemstore straffesager foreslog Hurwitz i skiftende udgaver af Den danske Strafferetspleje, første gang i 1940, et enhedssystem for lægdommere ved indførelse af domsmænd i de få nævningesager, idet han udtalte: "Dette Dobbeltsystem [både domsmænd og nævninger] ... bærer paa iøjnefaldende Maade Præg af at være et i og for sig irrationelt Overgangssystem" (1. udgave, 1940, p. 86 f.). Siden domsmændenes indførelse er hengået omtrent 66 år, og jeg håber, at vi, når halvfjerdsåret oprinder, kan hilse en ny reform velkommen.

I 1998 kom reformbestræbelserne så tæt på som ingensinde før, nemlig ved Retsplejerådets betænkning nr. 1352/1998 om behandling af nævningesager. Udover en del nyttige småændringer foresloges på to afgørende punkter reformer, for det første ved indførelse af fællesvotering mellem nævninger og juridiske dommere i forbindelse med en opgivelse af spørgsmålssystemet, hvilket

\footnotetext{
* Indledningsforedrag ved Dansk Kriminalistforenings årsmøde d. 5. februar 2003.
}

** Title in English: Reforms of the Danish Jury System. Original in Danish. 
automatisk ville medføre begrundede afgørelser, for det andet ved indførelse af et appelsystem også for skyldspørgsmålets vedkommende, også et gammelt ønskemål. Den påfølgende debat blev noget sparsom - jeg erindrer kun to større indlæg, min egen tilslutning til forslagets hovedpunkter kombineret med en vis kritik af enkeltheder (Et godt forslag - men det kan forbedres. UfR 1998 B p. 215-22) samt Eva Smiths temperamentsfulde afvisning af fællesvoteringen (Et juridisk skoleridt. UfR 1998 B p. 470-75) først og fremmest på grund af en frygt for fagdommernes påvirkning af lægdommerne.

Høringssvarene var hovedsagelig velvillige. Kun Advokatrådet og Landsforeningen af beskikkede Advokater og tildels Det danske Center for Menneskerettigheder gik af samme grund som Eva Smith imod, alle andre anbefalede den foreslåede reform. Justitsministeren bebudede lovforslag i folketingssamlingen 1998-99, men besluttede derefter at udskyde reformen, ikke på grund af principielle betænkeligheder, men fordi den var blevet knyttet sammen med overvejelserne om domstolenes, særlig byretternes struktur. Den foreslåede nævningereform opererede nemlig med et system af nævningebehandling $\mathrm{i}$ to instanser, to dommere og seks nævninger i byret efterfulgt af tre dommere og ni nævninger i landsret, hvilket skabte problemer ved byretsbehandlingen, idet flertallet af de 82 danske retskredse kun har én udnævnt dommer. Strukturkommissionens betænkning nr. 1398/2001 foreslog sammenlægning til kun 25 retskredse med et minimum af 6 dommere i hver, i høj grad af hensyn til den borgerlige retspleje det kommer jeg ikke videre ind på her - hvorved der uden vanskelighed kunne afses to dommere til nævningesagerne. En nævningereform venter herefter på løsningen af strukturspørgsmålet, men denne trækker muligvis ud yderligere en del år. For det første er den foreslåede ændring politisk omstridt, især fordi mange kommuner protesterer imod at miste deres selvstændige dommere med det deraf følgende tab af et lokalt juridisk milieu, og for det andet er der nu rejst spørgsmål om ændring af rigets kommunale inddeling, herunder ved en sammenlægning af de eksisterende 277 kommuner til højst hundrede, måske helt ned til 50 kommuner. Da det har været et aksiom, at en kommune ikke må deles mellem flere retskredse, er det uundgåeligt, at en ændring af retskredsene afventer kommunesammenlægningerne. Altså: da kommuneinddelingen betinger retskredsinddelingen og denne betinger nævningereformen, er sidstnævnte meget muligt udskudt $i$ to led. I sin tid tog det 12-15 år fra de første overvejelser om ændring af den kommunale inddeling indtil den store reform af 1973, og jeg tror ikke på, at det vil gå meget hurtigere denne gang.

Det er derfor ikke uden interesse at overveje, om nævningespørgsmålet kan frigøres fra retskredsinddelingen, og lidt mindre ambitiøst, men måske mere realistisk, om der er behov og praktisk mulighed for at gennemføre partielle reformer kombineret med en udskydelse af den store gennemgribende reform indtil vi kender retskredsstrukturen. Jeg har i en nylig artikel (Siamesiske tvillinger. UfR 2002 B p. 315-23) slået til lyd for, at lovgiver nu hvæsser operati- 
onskniven og adskiller de siamesiske tvillinger, og jeg er taknemlig for at have fået denne lejlighed til at redegøre nærmere herfor i denne kreds.

Det er i øvrigt ikke første gang, lægdommere har været hovedemnet ved et årsmøde i Dansk Kriminalistforening. Ved det fireogtyvende årsmøde i februar 1931 indledte foreningens senere formand, professor Oluf Krabbe, om emnet Domsmaend og den nye Straffelov. Mødet blev et af de mere stormfulde i foreningen.

Seks punkter vil jeg omtale i det følgende: Er en reform overhovedet ønskelig? Er en reform påkrævet nu? Hvordan bør nævningesager organiseres i første instans? Hvordan bør de føres i anken? Bør nævningebehandling ophæves i enkelte saggrupper? Kan og bør der indføres mindre delreformer på det i dag eksisterende grundlag?

Et enkelt punkt vil jeg kun nævne her og i det følgende forbigå: Jeg er aldeles sikker på, at de af Retsplejerådet foreslåede reformer er grundlovsmæssige, og peger på, at dette var opfattelsen hos det samlede Retsplejeråd, også de to advokatrepræsentanter, som af andre grunde dissentierede imod forslaget.

\section{Reformens ønskelighed}

Måske kunne jeg nøjes med at sige ja og overgå til det næste punkt, da svaret på dette spørgsmål for mange er en trossag, hvor standpunktet ikke kan rokkes ved kølig argumentering. Jeg véd godt, at jeg aldrig kan overbevise Eva Smith eller de forsvarere, som kender og elsker de eksisterende nævningesager, men jeg håber på at overbevise både Justitsministeriet og derigennem flertallet i Folketinget og vil derfor alligevel sige lidt om også dette punkt.

Lad mig straks pointere, at jeg ikke ønsker at nedvurdere danske nævninger og ikke er af den opfattelse, at nævningetingenes afgørelser er "forkerte" - i min skriftlige version af dette indlæg har jeg sat ordet i anførelsestegn, da vi jo aldrig kan sige med fuldstændig sikkerhed, om en, skal vi sige uventet afgørelse, er rigtig eller forkert. Danske lægdommere er dygtige og interesserede; jeg kender dem ganske vist kun som domsmænd - min egen kortvarige erfaring med nævninger ligger mere end tyve år tilbage fra min konstitution i Østre Landsret men landsrettens lægdommere, som jeg kender derved, at de ofte skifter mellem by- og landsret, er jo både domsmænd og nævninger, og der er ingen grund til at tro, at de er mindre seriøse som nævninger end som domsmænd. Måske endog tværtimod! Min positive holdning til lægdommere i det hele taget er den væsentligste forskel på min opfattelse og bl.a. Krabbes i 1931. Krabbes ord, at af samfundsopgaver krævede kun f.eks. snekastning på landet de enkelte borgeres personlige medvirken, men ikke dommervirksomhed, gør jeg ikke til mine.

At det går så godt, skyldes efter min opfattelse, at lægdommere udpeges, ja vælges, men ikke udtages ved lodtrækning eller efter andre tilfældighedskriterier. De kommunale grundlisteudvalg, som udpeger dem, foretager ganske simpelt en positiv udvælgning, og jeg håber meget, at alle tendenser i retning af 
lodtrækning eller anden tilfældighedsudtagning manes i jorden igen, men det er en anden historie.

Når jeg alligevel er en helhjertet tilhænger af en ændret ordning, hvorved fællesvotering mellem juridiske og læge dommere - som vi i dag kender den i domsmandsretterne - også indføres i nævningetingene, skyldes det således ikke en nedvurdering af lægdommerne. Den separate votering medfører derimod alvorlige skavanker. Man kan ikke afkræve lægdommere en begrundelse for deres resultat, og selvom der kan lappes på det ved at afkræve de juridiske dommere, som jo voterer samtidig og særskilt, en begrundelse for deres votum, ændrer det ikke ved, at nævningerne kun kan svare "ja" og "nej" på specifikt stillede spørgsmål. Der kan være tale om mange spørgsmål og mange gradueringer, nævningebetænkningen af 1998 opstiller en række på 10 tillægsspørgsmål til samme hovedspørgsmål om forsætligt drab. Risiko for misforståelse kan ikke altid udelukkes; den klassiske fejlkilde er, at nævningerne svarer ja og dermed mener, at tiltalte objektivt er gerningsmand, medens det ikke er spor sikkert, at nævningerne også fandt et strafbart forsæt bevist. Ved en fællesvotering ville retsformanden straks kunne få misforståelsen opklaret. Spørgsmålssystemet medfører også, at ganske vitale faktiske spørgsmål aldrig besvares, særlig om sådanne faktiske omstændigheder, som ikke er en del af selve forbrydelsen, men alligevel afgørende farver forbrydelsens strafværdighed. Om den dræbte i en drabssag groft har krænket morderen kort inden drabet, betager ikke drabsmanden hans skyld, men kan alligevel være af stor betydning for strafudmålingen. Nævningernes ja viser ikke, om de har fundet forudgående provokation bevist eller ej, og de juridiske dommere, som jo deltager i strafudmålingen, kan være i tvivl om, hvilket faktiske hændelsesforløb der er lagt til grund.

Det gældende system medfører andre vanskeligheder. Særlig foregår en skamridning af både formalia og af genoptagelsesinstituttet. I ingen saggruppe ses så mange luftige juridiske formalitetsindsigelser og i ingen en tilsvarende kolossal frekvens af genoptagelsesbegæringer. Jeg nævner dog kun dette argument en passant, da indførelse af en ankeordning, som jo godt kan forenes med separat votering, nok vil afhjælpe nogle af disse svagheder.

Det bedste, ja det eneste argument for en bibeholdelse af den separate votering, som fortjener en grundig overvejelse, er frygten for, at de(n) juridiske dommer(e) sætter sig på lægdommerne, så at disses egen vilje bøjer sig under dommerens vilje. Særlig forsvarerdeltagere i debatten fremfører dette argument; synspunktet er lidt groft sagt og karrikeret formuleret, at folkelige lægdommere med ubestemte sympatier for the underdog - ad modum Henry Fonda i filmen Tolv vrede Mand - ville have frifundet, hvis de havde fået lov til at afgøre sagen selv, men tromles ned af dommere udpegede fra en kreds af gamle anklagere. Hvis det virkelig var tilfældet, burde vi straks omdanne alle vore domsmandsretter til nævningeting. Sandheden er jo, at vi har 10-12.000 domsmandssager pr. år med fælles votering nærmest uden kritik, medens separat votering anven- 
des i mindre end 100 nævningesager hvert år. Der er altså ikke tale om en radikal omdannelse og svækkelse af lægdommersystemet, men om at få den sidste procent ind på linie med resten af sagerne.

Det er også overtro, at juridiske, udnævnte dommere under dagens samfundsmæssige forhold kan "sætte sig på" lægdommerne. Hvis jeg forsøgte det, ville det give totalt bagslag. Enten ville domsmændene, som jo er to mod én, øjeblikkelig rebellere og stemme mig ned, eller også, mere sandsynligt, ville de bøje sig nu, men derefter nære et sådant ressentiment, at alt tillidsfuldt, af gensidig sympati og respekt præget samarbejde ville være aldeles ødelagt i resten af den fireårsperiode, hvor denne dommer skal samvirke med disse domsmænd. Modne, erfarne domsmænd lader sig ikke tyre, hverken af en gammel dommer eller en yngre dommerfuldmægtig.

Dette betyder selvfølgelig ikke, at dommeren skal være passiv og blot lade sig styre ud fra en tåget respekt for de folkevalgte dommere. Dommeren har sit eget votum; han har normalt langt større erfaring end lægdommerne, og han har modsat disse - bør i det mindste have - de juridiske kundskaber, som er nødvendige til at løse de lejlighedsvise retlige spørgsmål. Jeg husker sager, hvor det var nødvendigt nøje at forklare domsmændene den ganske intrikate forskel mellem trusselsbegrebet i straffelovens $\S 123$ og $\S 266$. I den sidstnævnte bestemmelse kræves meget for at antage en objektiv overtrædelse, men til gengæld er alle trusler strafbare uanset formålet og motivationen; i den førstnævnte inddrages også de i sig selv mindre alvorlige trusler, men til gengæld kræves en kausal eller motivisk forbindelse mellem truslen og en forklaring til retten eller politiet. Det er ikke nemt stof, men det kan forklares, og det er nu engang lettere at gøre det, når spørgsmålet opstår direkte, end $i$ en lang retsbelæring som i de klassiske nævningesager. Når vi når strafudmålingen, kender dommeren praksis og véd, hvad man plejer at gøre. Det udelukker ikke afvigelser op eller ned, men i det mindste skal man kende praksis, også hvis man ønsker at fravige den. Selvfølgelig giver dommerens større viden og erfaring et forspring ved overvejelserne, men det ser jeg intet forkert ved.

Ret beset sker det i øvrigt lige så hyppigt, at domsmændene påvirker, ja overbeviser dommeren, som den modsatte vej rundt, eller måske bedre, det resultat, som dommer og domsmænd når i fællesskab, er normalt bedre end de tre medvirkendes separate vota lagt sammen. Formålet med kollegial behandling, hvad enten det sker i et rent juridisk eller et blandet kollegium, er nu en gang ikke dissens, men konsensus på et højere plan.

\section{Reform nu}

Dette punkt kan gøres kortere. I 1999 havde jeg forståelse for, at Justitsministeriet satte reformen i bero på strukturovervejelserne. Når vi havde ventet så længe, kunne vi godt vente de yderligere år, og som før omtalt går det jo i det store og hele ganske godt. 
Men nu trænger reformen sig mere på, først og fremmest på grund af kombinationen af tre nye elementer: For det første er det min erkendt løselige opfattelse, at medens den samlede kriminalitet er stagnerende eller endog faldende, er der en stigning i de alvorligste forbrydelser, som kan gå i nævningeting. For det andet er tilbøjeligheden til at tilstå og få sagen fremmet efter rpl. § 925, undskyld $\S 922$, mindre nu end før. Dette er ikke et indlæg om udlændinge som gerningsmænd, og jeg har ingen statistisk støtte for min opfattelse, men det er min og formentlig andre straffedommeres erfaring, at sigtede med anden etnisk oprindelse end dansk tilstår mindre og i højere grad håber på heldet. Jeg vover også pelsen ved at sige, at en mere aktiv, til tider aggressiv forsvarerstil medfører, at færre store sager kan fremmes som tilståelsessag. For det tredie og mest akut tilsigter den nylige skærpelov nr. 380 af 6. juni 2002 så betydelige skærpelser i strafudmålingen særlig i sager om vold og voldtægt, at der stadig oftere vil opstå sager, hvor anklagemyndigheden må overveje, om der bør kræves straf på fængsel i 4 år eller mere, og om nævningebehandling af denne grund bliver indiceret. Når standardstraffen for ét forhold af overfaldsvoldtægt hæves fra halvandet års fængsel til halvtredie år, skal der ikke meget yderligere til, før statsadvokaten skal overveje, om sagen skal rejses ved domsmandsret eller nævningeting.

I mangel af en hurtig reform risikerer vi en måske betragtelig udvidelse af antallet af nævningesager, også fordi det må forventes, at statsadvokaterne $\mathrm{i}$ selvfølgelig loyalitet mod intentionerne bag den store skærpelov vil afprøve dennes rækkevidde, hvilket forudsætter, at retterne ikke bindes af et strafmaksimum på 3 år 11 måneder, hvilket atter medfører, at den indtil nu kendte praksis, hvorved sager med et teoretisk strafniveau på op til måske 5 år af procesøkonomiske grunde rejses for byret, vil blive opgivet. En sådan ændret tiltalepraksis vil blive belastende for landsretterne. Den gennemsnitlige varighed pr. nævningesag ligger i følge Anklagemyndighedens Årsberetning mellem fire og fem dage, hvor en domsmandssag om det samme forhold utvivlsomt vil kunne gennemføres på højst to dage, måske en enkelt dag. Berammelserne vil trække ud med særlig længere fængslingsperioder til følge etc.

Sammenfattende ad dette punkt er det min opfattelse, at en reform trænger sig mere på nu end for blot et par år siden.

\section{Sagernes behandling i første instans}

Dette er et af de vigtigste punkter og det, hvor min uenighed med betænkningen af 1998 er størst. Retsplejerådet havde to hovedmodeller at vælge imellem, nemlig domsmandsbehandling i byretten, således at nævningebehandling kun skulle finde sted i ankeinstansen, og nævningebehandling i begge instanser. Den første løsning er indført i Norge ved den såkaldte "to-instansreform" med virkning fra 1. juli 1995, den anden løsning svarer til et forslag fra von Eyben i 1991, men er vist ikke kendt i praksis i noget retssystem; en sådan reform blev dog foreslået i Frankrig i 1995-97, men blev atter opgivet efter et regeringsskifte i 1997, delvis af finansielle grunde. 
Retsplejerådet valgte efter en urimelig kortfattet omtale af den norske ordning og med en næsten lakonisk argumentation ordningen med nævningebehandling $\mathrm{i}$ begge instanser. Det afgørende argument var, at allerede første instans burde behandle sagen optimalt, hvorved man kunne håbe på, at flest mulige sager afgjordes endeligt i byretten, eller sagt på en anden måde, man befrygtede en ankefrekvens på opimod $100 \%$, hvis der først var mulighed for nævningebehandling $\mathrm{i}$ anken, men håbede på, at i hvert fald nogle ville opgive at gå videre, hvis nævninger medvirkede allerede i første instans.

Jeg anser dette argument som lovlig fortænkt $\mathrm{g}$ har vanskeligt ved at forestille mig, at den tiltalte, som just er idømt en meget langvarig fængselsstraf, vil undlade at appellere efter en overvejelse om graden af den processuelle betryggelse ved nævningebehandling snarere end domsmandsbehandling. Efter min opfattelse vil ankeprocenten, hvis tiltalte dømmes trods benægtelse, altid være meget høj uanset arten af procesform. Men i øvrigt viser de norske erfaringer efter nyordningen, at ankefrekvensen ikke er voldsomt høj i sager med strafmaksimum over 6 år - det norske nævningekriterium - og fuldstændig anke til jury; i størstedelen af perioden efter 1995 er ankeprocenten omkring 40 og kun i 2001 lige over 50. Tallene er ufuldstændige - særlig har jeg ikke fået oplyst, hvor mange tilståelsessager der skjuler sig i materialet - men det er i det mindste nærliggende for den danske lovgiver at studere de norske erfaringer nøjere, inden man låser sig fast på den tungere procesform.

Snarere vil jeg anbefale domsmandsret $i$ første instans med mulighed for forstærket besætning i de allerstørste sager efter et konkret skøn, d.v.s. 2 fagdommere og 3 domsmænd i stedet for $1+2$. Langtfra alle sager med en sanktionspåstand på fængsel på 4 år eller mere eller anbringelse er så indviklede, at de kræver forstærket besætning af retten; f.eks. vil lufthavnssagerne med et større kvantum heroin i kufferten, hvor det eneste mulige forsvar er et anbringende om god tro, eller oplagte drabssager med anbringelse i sindssygehospital som den eneste realistiske sanktion sagtens kunne behandles af en ordinær domsmandsret i første, måske eneste instans. Sager af et omfang som i sin tid Blekingegadesagen kræver derimod oplagt en forstærket sammensætning af retten, men ikke nødvendigvis nævningebehandling.

Jeg er klar over, at Retsplejerådet nødvendigvis måtte arbejde i blinde under forberedelsen af betænkningen af 1998, idet den norske nyordning da var så frisk, at der ikke var nogen erfaringer at dømme efter. Men nu er den norske ordning så indarbejdet, at der må ligge et fyldigt materiale, og jeg må meget anbefale, at Justitsministeriet, inden der udarbejdes lovforslag og tages endelig stilling, sender nogen til Norge med en anbefalingsskrivelse til Det Kgl. Justisdepartement og/eller indhenter et responsum fra f.eks. høyesterettsdommer Magnus Matningsdal, som har skrevet den gængse fremstilling om den nye ankeordning. Dette arbejde kan sagtens igangsættes straks uden afventning af en løsning af strukturproblemet, og skulle overvejelserne resultere i valg af den 
enklere domsmandsløsning, ville reformen kunne iværksættes straks og frigjort fra strukturovervejelserne.

Inden jeg forlader dette punkt, vil jeg blot nævne, at min egen forening, Den danske Dommerforening, anbefaler domsmandsbehandling i første instans.

\section{Sagernes behandling $\mathrm{i}$ anken}

Under alle omstændigheder må nævningebehandling fastholdes i anden instans. Jeg er ikke så urealistisk, at jeg under den givne retspolitiske virkelighed vil foreslå en totalophævelse af nævningeinstitutionen, hvilket i øvrigt meget muligt ville være grundlovsstridigt. Med Retsplejerådet er jeg også enig om den foreslåede hovedreform, fællesvotering med ophævelse af spørgsmålssystemet. Det vigtigste, ja afgørende udbytte ved en sådan reform vil være, at vi endelig opnår mulighed for begrundede afgørelser af skyldspørgsmålet. Den reform har været urimelig længe om at bane sig vej.

Det er derimod min opfattelse, at Retsplejerådet ikke i tilstrækkelig grad er gået ud i krogene ved den nærmere udformning af de foreslåede regler. Området for nævningebehandling må være afgørelsen af skyldspørgsmålet i sager, hvor der opstår spørgsmål om straf af fængsel i 4 år eller mere, og videre bør grænserne ikke drages. Jeg kan umiddelbart påpege to situationer, hvor Retsplejerådets forslag indebærer overflødig nævningebehandling. I den første situation er tiltalte i byretten frifundet for drabsforsøg - typisk straf fængsel i 6 år - og for grov vold idømt fængsel i 3 år. Under anken påstår tiltalte frifindelse, medens anklagemyndigheden påstår stadfæstelse af skyldspørgsmålet og straf under 4 år. Her må nævningebehandling være overflødig, også selvom nævninger måtte have medvirket $\mathrm{i}$ første instans. Den anden situation er endnu klarere, nemlig begrænset anke, som ikke omfatter skyldspørgsmålet. Det kan umulig være påkrævet, at et nævningeting skal afgøre, om den rette straf skal være 2 år strengere eller mildere, hvis skyldspørgsmålets afgørelse ikke anfægtes. Her må domsmandsbehandling være tilstrækkelig, svarende til anke i $\S 922$-sager og i øvrigt til norsk ret.

Jeg skal ikke forfølge dette punkt nærmere her, men opfordre til, at Justitsministeriet, når lovforslag engang skal udarbejdes, ikke blot kalkerer 1998betænkningens forslag af, men foretager selvstændige overvejelser, og det er ikke kun forfængelighed, som besjæler mig, når jeg udtrykker håb om, at min artikel fra 1998 indgår i materialet.

\section{Ophævelse af nævningebehandling i enkelte saggrupper}

En betydelig nemmere måde at "reformere" nævningeinstitutionen på ville være at ophæve nævningebehandling i enkelte saggrupper. I Danmark var lige fra indførelsen af strafferammekriteriet i 1932 sagerne efter straffelovens $\S 286$ stk. 2 undtagne, og i 1962 ophævedes nævningebehandling i sager om dokumentfalsk. Ved indførelsen af det nye kriterium for nævningebehandling i 1984, 
strafpåstand i 4 år eller derover, undtoges også grov skattesvig, strfl. § 289.

I 1974 og påny i 1975, hvor strafferammen for de groveste narkotikaforbrydelser forhøjedes fra 6 til 10 år, d.v.s. udover den daværende nævningegrænse på 8 år efter strafferammekriteriet, foreslog Justitsministeriet alle narkotikasager undtagne fra nævningebehandling, idet de efter deres ofte meget specielle karakter fandtes mindre egnede hertil, men Folketingets retsudvalgs flertal fastholdt uden nærmere begrundelse de generelle regler. Spørgsmålet blev ikke rejst igen ved ændringen af nævningekriteriet i 1984, d.v.s. at de større narkotikasager fortsat behandles for nævninger, hvis de ikke kan fremmes efter reglerne i $\S$ 922.

Under høringen i anledning af 1998-betænkningen fremhævede politidirektøren, at et nævningesystem $\mathrm{i}$ to instanser måtte forventes at blive mere ressourcekrævende end det eksisterende system, og foreslog til overvejelse, om kompetencereglerne burde ændres således at kun de mest alvorlige straffesager behandledes som nævningesager, enten ved forhøjelse af 4 årsgrænsen eller ved at undtage flere sager fra nævningebehandling, f.eks. narkotikasager, som ofte er meget komplicerede og ikke sjældent har mange tiltalte i samme sag.

Landsforeningen af beskikkede Advokater har gentaget det gamle forslag om ophævelse af nævningebehandling i narkotikasager (Meddelelser fra Landsforeningen af beskikkede Advokater 11/2001, p. 289 ff.). Der henvises til sagernes ofte komplekse, tekniske og langstrakte karakter og til den ofte forekommende uklarhed med hensyn til kvantum og art af det relevante narkotiske stof og uklarhed om de nærmere omstændigheder omkring det kriminelle forhold, hvilket på grund af spørgsmålssystemet nødvendiggør en række subsidiære hovedspørgsmål, som kan gøre nævningernes opgave noget uoverskuelig. Erfaringerne fra de forløbne ca. 25 år efter nævningesystemets indførelse i de største narkotikasager viser, at disse sager egner sig bedst til domsmandsbehandling. Landsforeningen er på det rene med, at forslaget samlet set vil medføre en merbelastning af både byretter og landsretter, bl.a. fordi mange af sagerne må forventes ankede, når bevisanke nu muliggøres.

Jeg finder, at forslaget fra Landsforeningen fortjener betydelig opmærksomhed, så meget desto mere som foreningen ikke i øvrigt ønsker reglerne om nævningebehandling ændrede, men foretrækker det gældende system opretholdt for de øvrige sager, altså først og fremmest drabssagerne.

Forslaget er åbenlyst velbegrundet; også en inkarneret kritiker af nævningesystemet $\mathrm{i}$ dets nuværende form må finde særlig en drabssag, hvor det afgørende tvistepunkt typisk vil være det ene store spørgsmål, om tiltaltes hånd var på det dræbende våben eller ej, klart mere egnet til nævningebehandling end narkotikasager og særlig bandesager. Desuden har forslaget den yderligere fordel, at det kan gennemføres, hvadenten retskredsstrukturen ændres eller ej, således at det ville kunne fremsættes og gennemføres hurtigt. Selvom strafskærpelsen i volds- og sædelighedssager måtte medføre flere nævningesager på disse felter, 
ville der alligevel opstå et pusterum, inden den afgørende reform trænger sig på.

Under debatten oplyste landsdommer Niels Johan Petersen, Østre Landsret, at landsretten i 2002 gennemførte 51 nævningesager (4 yderligere sager bortfaldt), 12 eller 23,5\% narkotikasager, 39 eller 76,5\% andre sager. At narkotikasagerne var de mest byrdefulde, ses ved, at de 12 sager optog 93 dage af 248 eller $37,5 \%$, de andre sager 155 dage eller $62,5 \%$. Den seneste narkotikasag varede 34 dage og førtes mod 10 tiltalte med hver sin forsvarer og hver sin tolk; der var 140 spørgsmål; afspilning af aflyttede telefonsamtaler, det vigtigste bevis, varede flere dage, og nævningerne fik ca. 400 A4-sider udskrift af aflytningerne; nævningerne måtte anmode om læsepauser. Der var ikke retssale nok til de store sager med mange tiltalte. De lange sager medførte begæringer om fritagelse fra de udtagne nævninger, som ikke kunne afvises; nævningetingene måtte nødvendigvis fyldes af pensionister og efterlønsmodtagere, de eneste som havde tid. Det var i øvrigt hans erfaring, at lægdommerne i København ikke længere valgtes med omhu, men i vidt omfang udtoges gruppevis ved lodtrækning. Han troede ikke på, at fællesvotering var politisk gennemførlig, men plaiderede indtrængende for delreformer, særlig ved ophævelse af nævningebehandling i narkotikasager samt de nye sager om menneskesmugling, som utvivlsomt ville medføre de samme vanskeligheder.

\section{De blandede sager}

Ifølge Rpl. § 688, 1. pkt., tidligere § 690, kræves i straffesager med flere forhold nævningebehandling, "hvis sådan behandling efter reglerne i § 687 kræves med hensyn til en af overtrædelserne". Reglen fik sin nuværende udformning i 1979, hvor det tilsigtedes og opnåedes, at hvis sagen omfattede et tilstået forhold, som, hvis det var benægtet, ville have medført nævningebehandling, og benægtede forhold, som ikke i sig selv medførte nævningebehandling, ville den samlede sag være undergivet domsmandsbehandling. Da betingelserne for nævningebehandling i 1984 ændredes ved, at det gamle kriterium, lovens strafferamme for hvert enkelt forhold for sig, afløstes af kriteriet konkret påstået straf i den samlede sag, forblev reglen i $\S 690$ desværre uændret, selvom den nok kunne have fortjent en grundig revision.

Problemet er som før de sager, som omfatter både overtrædelser, som er direkte undtagne fra nævningebehandling, og overtrædelser, som vil kunne medføre sådan behandling, hvis strafpåstanden er høj nok. Indtil 1984 var løsningen enkel og § 688 (§ 690) en god hjælp: Hvis intet forhold isoleret ville kræve nævningebehandling, var denne behandling også udelukket for den samlede sag. Men efter 1984 kunne man komme i den paradoksale situation, at hvis sagen omfattede både uvoldelige formueforbrydelser, som ikke ville medføre nævningebehandling, og forhold, som kunne medføre sådan behandling, ville den samlede sag komme for nævningeting, hvis den samlede straf nåede 4 år eller mere, uanset om kun en mindre del af straffen skyldtes "nævningeforhol- 
det". § 688 yder ingen fortolkningshjælp, idet den fortsat foreskriver nævningebehandling, hvis dette kræves for "en af overtrædelserne". Men det er jo ikke tilfældet, hvis nævningebehandling alene er et resultat af den samlede strafpåstand.

I Hillerød kriminalret fremkom lige efter 1984-ændringen en sag, hvor overtrædelser af straffelovens $\S 191$ kombineredes med betydelige tyverier. Tiltalte nægtede sig stort set skyldig. Var de to grupper af forhold rejst ved to separate anklageskrifter, ville tiltalte formentlig være idømt fængsel i 3 år i begge sager. Jeg anskuede de to sagskategorier hver for sig og antog, at nævningebehandling ikke krævedes for "en af overtrædelserne" jfr. princippet i § 690, hvorefter jeg med domsmænd idømte tiltalte fængsel i 6 år. Under anken påstod tiltalte frifindelse, men ikke henvisning til nævningeting. Landsretten og Højesteret ophævede dommen og henviste sagen til nævningebehandling, UfR 1986,518 $\mathrm{H}$, under hensyn til, at der efter anklagemyndighedens påstand blev spørgsmål om straf af fængsel i 4 år eller derover, samt til tiltaltes stilling til skyldspørgsmålet. Det hører med til historien, at ved upåanket nævningedom fandtes tiltalte skyldig i stort set samme overtrædelser og idømtes den samme straf af fængsel i 6 år.

UfR 1986,518 H har fastlagt grænserne de lege lata, men den valgte løsning jeg er ikke overbevist og finder fortsat, at udfaldet ikke var oplagt, men at Højesteret lige så godt kunne have kuldlyst min løsning - er aldeles upraktisk. Forbrydere opfører sig ikke altid så hensynsfuldt, at de holder sig til den samme paragraf i straffeloven. Lidt paradoksalt kan man sige, at de uvoldelige forbrydere stilles ringere end voldsmændene. En nylig afsluttet celeber dokumentfalsksag fremmedes som domsmandssag i begge instanser med straffe på 6 år og 4 år, altså over nævningegrænsen, hvis nævningebehandling ikke havde været udelukket. Som hele riget blev vidne til, skældte de to tiltalte hinanden hæder og ære fra for fuld offentlighed, men heldigvis for sagens behandling havde de det kun i munden; havde en af dem tildelt den anden et forsvarligt knytnæveslag, burde anklagemyndigheden fornuftigvis undlade tiltale for vold eller rejse denne sag separat. Hvis blot ét forhold efter strfl. § 244 var kravlet ind i sagen, ville enten den samlede sag have været nævningesag eller domsmandsretten være udelukket fra at udmåle en strengere straf end fængsel i 3 år 11 måneder. At "nævningeforholdet" ikke ville have medført en dags strengere straf, ville være uden betydning. Som jeg læser $§ 688$ i lyset af UfR 1986,518 H, vil enhver kombination indeholdende "nævningeforhold" kræve nævningesag, også selvom strafferammen for dette forhold ikke når 4 år, hvis blot straffen herfor indgår i den samlede straf, og denne når 4 år. Højst ville benægtede rene bødeforhold kunne includeres i tiltalen for de forhold, hvor nævningebehandling er udtrykkeligt udelukkede, men ikke engang det er jeg sikker på.

Paradokset har vist sig med særlig tydelighed i en nylig sag fra Slagelse, afgjort i anken ved Østre Landsrets dom af 19. december 2002 (11. afd. a.s. S- 
2984-01). Hovedmanden dømtes for hele 471 bedragerier eller forsøg derpå og 35 forhold af dokumentfalsk eller forsøg til en samlet sum af over 9 mill. kr., normalt i den form, at han og medgerningsmænd formåede usolide personer til at optage lån i finansieringsselskaber og forretninger med henblik på varekøb $\mathrm{og} / \mathrm{eller}$ udbetaling af kontantbeløb, videresalg af disse lånefinansierede indkøbte varer m.v., og havde tiltalen alene omfattet disse forhold, var straffen utvivlsomt blevet ikke så lidt højere end fængsel i 4 år. Men det var hans held, at han derudover var tiltalt - og blev dømt - for vold eller forsøg derpå i 11 tilfælde, ligesom han var tiltalt for overtrædelse af straffelovens narkotikabestemmelser.

Anklagemyndigheden påstod ved sagens rejsning en meget høj straf med udnyttelse af hele strafferammen til 8 år, måske mere, idet der henvistes til strfl. $\S 88$ stk. 1,2. pkt., men henimod slutningen af domsforhandlingen for byretten, hvor der ikke længere kunne være mulighed for omgørelse af tiltalen, gik den ubehagelige sandhed op for anklagemyndigheden, som nu "præciserede" dommens formulering - strafpåstanden til en straf så tæt på 4 år som muligt, idet man erklærede sig enig i, at straffen skulle være under 4 år, "jfr. § 687 og § 688". Hovedmanden idømtes herefter fængsel i 3 år 8 måneder og de medskyldige let lavere straffe. Landsretten, som dømte i videre omfang, skærpede straffen til 3 år 11 måneder og bemærkede udtrykkeligt, at som følge af tiltalerejsningen ved byret kunne straffen alene fastsættes til et tidsrum mindre end 4 års fængsel.

I en verserende sag ved Holbæk kriminalret om bedrageri i kolossalt omfang har anklagemyndigheden belært af de uheldige erfaringer i sagen fra Slagelse udrenset alle forhold, som ikke udtrykkelig ved loven er udelukkede fra nævningebehandling. Forsigtigheden, som jeg bifalder, går så vidt, at man ikke engang medtager accessoriske overtrædelser, f.eks. strfl. § 165 om falsk anmeldelse i forhold til assurancesvig.

At dette er en aldeles irrationel retstilstand, kan der ikke være to meninger om. Hvis lovgiveren undtager flere saggrupper fra nævningebehandling, særlig narkotikasager, bliver risikoen for blandede sager endnu større og behovet for en praktisk løsning endnu mere akut. Naturligvis kan man undgå fortolkningstvivl ved helt at ophæve $\S 688$ som foreslået af Retsplejerådet i 1998-betænkningen tillige med en præcisering af, at blandede sager kræver nævningebehandling, hvis betingelserne herfor er opfyldte efter anklagemyndighedens strafpåstand, men det løser ikke det praktiske problem om den fornuftigste processuelle behandling af blandede sager, hvor de overtrædelser, som ikke er undtaget fra nævningebehandling, kun har en ringe betydning for sagen, særlig for strafudmålingen. En bedre vej ud af moradset ville være en bibeholdelse af hovedprincippet i $\S 688$ tillige med en ændring, som skaber overensstemmelse med det siden 1984 rådende kriterium for nævningebehandling. Jeg har i min siamesiske artikel foreslået følgende formulering af $\S 688,1$. pkt. (2. pkt. er uden betyd- 
ning): "Straffesager, som både omfatter overtradelse af de i rpl. § 687 stk. 3, nr. 1, ncevnte bestemmelser og andre overtrcedelser, behandles ved landsret under medvirken af novninger, hvis sådan behandling efter reglerne $i \$ 687$ ville vare påkravet med hensyn til de overtradelser, som ikke er undtaget fra navningebehandling."

Det er min opfattelse, at i næsten alle sager, hvor problemet ville opstå, ville den hypotetiske beregning af den forventede straf for "nævningeforholdene" være let, og under alle omstændigheder bør i samtlige blandede sager dommen angive med klarhed, hvilken vægt der er tillagt de to grupper af forhold under sagen, hvis tiltale er rejst ved domsmandsret.

Også som en enkeltstående reform ville en ændring i denne retning løse det akutte problem om de blandede sager, men desuden ville den lette en yderligere reform, hvorved nye saggrupper, særlig narkotikasager, undtages fra nævningebehandling. I hvert fald bør de blandede sager reformeres omgående, også selvom nævningeprocessen ikke i øvrigt reformeres, og uden afventning af strukturovervejelserne.

\section{Epilog}

Nogle af de af mig foreslåede ændringer kan og bør gennemføres nærmest omgående, andre først efter nøje overvejelse. Men i det mindste bør reformen trækkes ud af mølposen og de siamesiske tvillinger nævningereform og strukturovervejelser adskilles operativt.

Jeg håber, at jeg, ligesom Jakob fik sin Rakel, kommer til at opleve en nævningereform, og at jeg ikke som en anden Moses ved afslutningen af vandringen gennem ørkenen må nøjes med at se ind i det forjættede land uden selv at komme ind i det, sådan som det gik Dansk Kriminalistforenings første formand Carl Torp, der døde i 1929 på tærsklen til gennemførelsen af den nye Borgerlige Straffelov, som han havde kæmpet for i hele sin trediveårige formandstid.

Adresse: Kriminalretten i Hillerød

Kannikegade 1

DK-3400 Hillerød 